Proc. Estonian Acad. Sci. Biol. Ecol., 2004, 53, 4, 269-275

\title{
Changes in the feeding behaviour of benthic invertebrates: effect of the introduced polychaete Marenzelleria viridis on the Baltic clam Macoma balthica
}

\author{
Jonne Kotta $^{\mathrm{a}^{*}}$, Helen Orav-Kotta ${ }^{\mathrm{a}}$, and Eva Sandberg-Kilpi ${ }^{\mathrm{b}}$ \\ ${ }^{a}$ Estonian Marine Institute, University of Tartu, Mäealuse 10a, 12618 Tallinn, Estonia \\ ${ }^{\mathrm{b}}$ Tvärminne Zoological Station, University of Helsinki, FIN-10900 Hanko, Finland \\ Received 10 March 2004, in revised form 6 August 2004
}

\begin{abstract}
The exploited feeding areas of Macoma balthica and Marenzelleria viridis were experimentally quantified in laboratory conditions. Our feeding trials showed that $M$. balthica was able to feed at a much wider surface area than $M$. viridis. Moreover, in the presence of $M$. viridis the feeding area of $M$. balthica and its cumulative increase in time were significantly higher than without the polychaete. These results suggest that $M$. balthica is superior to M. viridis in terms of feeding. The experiment supports the earlier findings that the presence of $M$. balthica appears to be a key factor limiting the further expansion of $M$. viridis in the northern Baltic Sea.
\end{abstract}

Key words: Baltic Sea, interspecific competition, invasion, Marenzelleria viridis, Macoma balthica.

\section{INTRODUCTION}

The North American detritus feeding polychaete Marenzelleria viridis (Verrill) was first found in the Baltic Sea in 1985 (Bick \& Burckhardt, 1989). To date $M$. viridis is practically established in the whole Baltic Sea and has become an important component of the macrozoobenthic communities (Olenin \& Leppäkoski, 1999; Kotta, 2000; Leppäkoski \& Olenin, 2001; Zettler et al., 2002).

The abundances of $M$. viridis in the northern Baltic Sea are however rather low, seldom surpassing 100 ind $\mathrm{m}^{-2}$ (Stigzelius et al., 1997; Kotta, 2000). High species diversity, increased food availability, low salinity, and uniformity of bio-

* Corresponding author, jonne@sea.ee 
tope facilitated the invasion of $M$. viridis in the northern Baltic Sea (Kotta, 2000; Kotta \& Orav, 2001; Zettler et al., 2002).

$M$. viridis is ranked among the most influential exotics in the region. The species is the only deep sediment burrower deposit-feeder in the northern Baltic Sea. An addition of a novel function has the potential to cause great ecological impacts (Simberloff, 1991; Ruesink et al., 1995). Due to the active bioturbation $M$. viridis most probably improves the oxygen regime in the sediment. Besides, the addition of an efficient deposit feeder into the benthic system is likely to offset a stress on the native fauna due to possible competitive interactions for food and/or for space.

There exists circumstantial evidence that after the invasion of $M$. viridis the densities of the shallow water amphipod Corophium volutator (Pallas) (Atkins et al., 1987; Zettler, 1996), the polychaete Hediste diversicolor (O. F. Müller) (Atkins et al., 1987; Essink \& Kleef, 1993; Kotta \& Kotta, 1998), and the deepwater amphipod Monoporeia affinis Lindström have dropped considerably (Cederwall et al., 1999). Experimental studies have demonstrated the negative effect of the polychaete on $H$. diversicolor and M. affinis (Kotta et al., 2001; Kotta \& Ólafsson, 2003; Neideman et al., 2003). However, the same experiments (Kotta et al., 2001) suggested that the dispersal of $M$. viridis in the northern Baltic Sea is probably not so successful in communities that are strongly dominated by the bivalve Macoma balthica $\mathrm{L}$.

In this study we compared the feeding of $M$. viridis and $M$. balthica in terms of exploited feeding area. The experiment involved treatments of a single species and the combination of the two species. Our hypothesis is that the superiority of $M$. balthica over $M$. viridis is likely to be gained by higher and more efficient feeding activity of the bivalve. That is (1) M. balthica should feed on a larger surface area than $M$. viridis and (2) the presence of $M$. viridis should induce higher feeding activity of $M$. balthica.

\section{MATERIAL AND METHODS}

An in situ experiment quantifying the feeding areas of the clam M. balthica and the polychaete $M$. viridis was carried out in the laboratory of the Tvärminne Zoological Station in the northeastern Baltic Sea in June 2000. Altogether 15 mesocosms of $1.5 \mathrm{~L}$ were used to permit 3 treatments replicated 5 times. We deployed the test animals both separately and together. The test organisms were added in accordance with their abundance values in the field. The density of $M$. balthica and $M$. viridis was 350 and 175 ind $\mathrm{m}^{-2}$, respectively. The average length of the test animals was $13.3 \pm 0.1$ and $44.3 \pm 2.5 \mathrm{~mm}( \pm \mathrm{SE})$, respectively.

In the experiment natural sedimented phytoplankton were added to the mesocosms every 48 hours, i.e. altogether three times. The surface area of invertebrate trails on sediment surface was regularly quantified by the aid of a digital camera (Fig. 1). Prior to each feeding trial the sediment surface was 


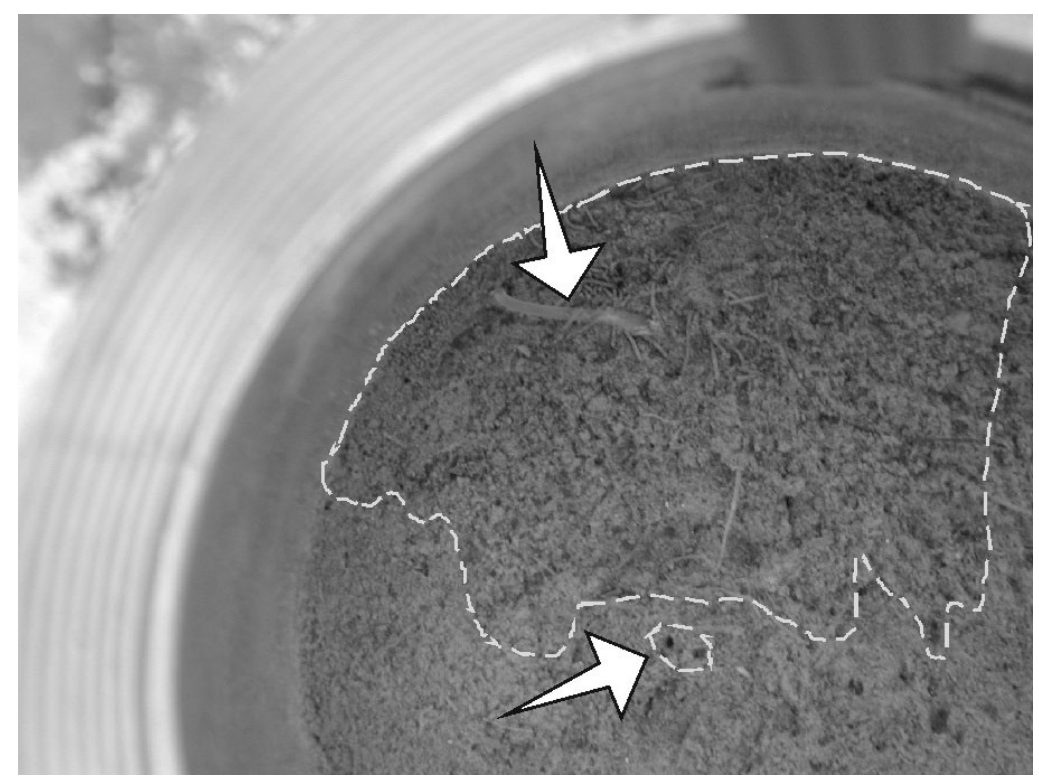

Fig. 1. A photograph of the feeding activity of the test animals: in the centre above the siphon of Macoma balthica and below two holes of the burrows of Marenzelleria viridis. Dashed lines indicate the feeding areas of both species.

carefully smoothen. The experiment lasted 5 days. We compared the cumulative increase in feeding areas between the studied species and the role of co-occurring species in affecting these functional responses. We employed polynomial linear regression analyses to describe the functional responses. The differences in the feeding areas between $M$. viridis and M. balthica were analysed by one-way ANOVA (Sokal \& Rohlf, 1981).

\section{RESULTS}

Our feeding trials indicated that $M$. balthica was able to consume detritus at a much wider surface area than M. viridis (Fig. 2; one-way ANOVA, all data of single species treatments included, $p<0.001)$. Moreover, in the presence of $M$. viridis $M$. balthica searched more actively for food than without the polychaete (one-way ANOVA, $p=0.003$ ). M. balthica exploited the whole surface area already in the first $5 \mathrm{~h}$ of the incubation whereas the feeding area of $M$. viridis did not change in the course of the experiment. M. viridis was highly sedentary and fed only within a few millimetre distance from its burrow. The presence of $M$. balthica had no effect on the feeding area of the polychaete (oneway ANOVA, $p=0.152$ ). 

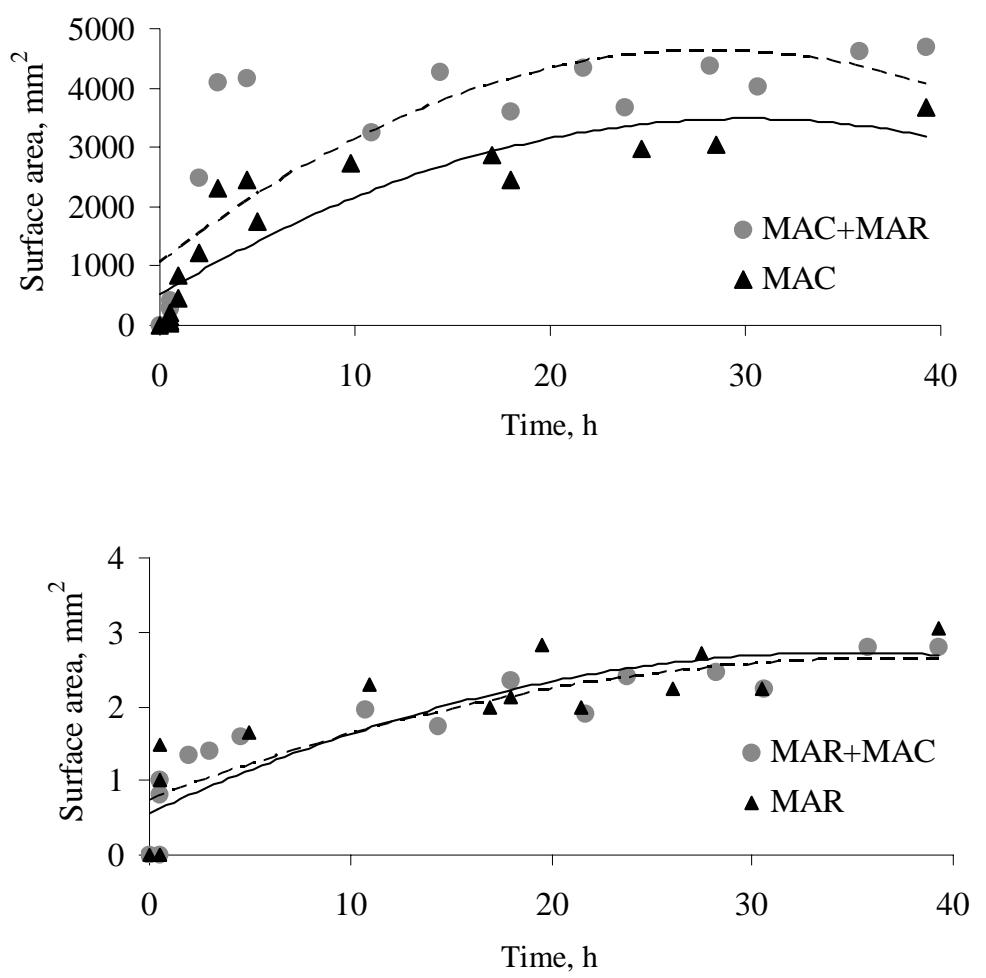

Fig. 2. Cumulative increase in the feeding area of Macoma balthica (MAC) and Marenzelleria viridis (MAR). The test animals were deployed both separately and together. The continuous line represents single species treatments and broken line the treatments where the two species were deployed together.

\section{DISCUSSION}

The polychaete $M$. viridis is primarily a subsurface deposit feeder and lives in sediment tubes. The feeding radius of the species is small unless the animal extends its body outside of the burrow. Occasionally, the polychaete may emerge from the tube in order to feed on sediment surface or perform suspension feeding (Zettler et al., 1994; Dauer, 1997; Bock \& Müller, 1999). The bivalve M. balthica is primarily a surface deposit feeder but may also graze pelagic microalgae by suspension feeding (Hummel, 1985; Ólafsson, 1986). The bivalve lives in the upper layers of sediment and sucks food by rotating movements of the tip of the siphon. New material is ingested by moving the siphon to a new position. Thus, due to similarities in feeding mode and habitat selection the two species may compete for both food and space.

The results of our trials agreed to the hypothesis that $M$. balthica is able to search for detritus at a higher rate and at a much wider surface area than M. viridis. M. balthica searched more actively for food in the presence of 
M. viridis, i.e. in the case of higher food limitation. The outcome of the experiment explains the earlier findings of the reduced survival of $M$. viridis in the presence of M. balthica (Kotta et al., 2001). Quick and efficient consumption of food resources typifies the opportunistic species and is beneficial in the areas where the amount of food varies highly. The prevalence of $M$. balthica in a temporally and spatially varying ecosystem such as the Baltic Sea is likely to be gained by the variety of efficient feeding modes and better tolerance of food shortages (e.g. Brafield \& Newell, 1961; Ólafsson, 1986).

Besides food competition our results do not exclude physical interference as the likely explanation for the outcome of the feeding trials. Although in some mesocosms the study animals were spatially separated the bivalves responded to the presence of the polychaete. The possible mechanism behind it may be that the bivalves sense and react chemical and/or tactile signals from the worms (e.g. McClintock \& Baker, 1997).

As M. balthica dominates on the soft bottom biotopes of the Baltic (Segerstråle, 1957; Hällfors et al., 1981) M. viridis should prevail only at the biotopes where the polychaete can avoid the bivalve. These are for example the sea areas adjacent to river mouths where the food for deposit feeders is in excess and the population of the bivalve is more stressed owing to low salinity. Consequently, the negative interactions between $M$. viridis and the resident fauna are less intense and the dominance of $M$. viridis is very likely in the areas (Kotta, 2000).

M. balthica is also missing in the deeper hypoxic water (Laine, 2003). This may explain the establishment success of the polychaete in the deeper waters of the northern Baltic Sea (Kotta, 2000). The ability of M. viridis to perform diel vertical migration (Dauer et al., 1981; Russel, 1995) is beneficial for the populations inhabiting deeper sites in order to survive the temporary anoxia that is a common phenomenon of the northern Baltic Sea. This is also in accordance with the invasion theory stating that invaders into natural aquatic systems are most likely to become established when native assemblages of organisms have been temporarily disrupted or depleted (Moyle \& Light, 1996).

\section{ACKNOWLEDGEMENTS}

This study was financed by the Estonian Target Financing Program No 0182578s03, Estonian Science Foundation grant No 5103, and EU CHARM project.

\section{REFERENCES}

Atkins, S. M., Jones, A. M. \& Garwood, P. R. 1987. The ecology and reproductive cycle of a population of Marenzelleria viridis (Annelida: Polychaeta: Spionidae) in the Tay Estuary. Proc. Royal Soc. London Edinburgh, 92B, 311-322.

Bick, A. \& Burckhardt, R. 1989. Erstnahweis von Marenzelleria viridis (Polychaeta, Spionidae) für den Ostseeraum. Mitt. Zool. Mus. Berl., 65, 237-247. 
Bock, M. J. \& Müller, D. C. 1999. Particle selectivity, gut volume, and the response to a step change in diet for deposit-feeding polychaetes. Limnol. Oceanogr., 44, 1132-1138.

Brafield, A. E. \& Newell, G. E. 1961. The behaviour of Macoma balthica. J. Mar. Biol. Ass. UK, 41, 81-87.

Cederwall, H., Jermakovs, V. \& Lagzdins, G. 1999. Long-term changes in the soft-bottom macrofauna of the Gulf of Riga. ICES J. Mar. Sci., 56 suppl., 41-48.

Dauer, D. M. 1997. Functional morphology and feeding behavior of Marenzelleria viridis (Polychaeta: Spionidae). Bull. Mar. Sci., 60, 512-516.

Dauer, D. M., Maybury, C. A. \& Ewing, R. M. 1981. Feeding behaviour and general ecology of several spionid polychaetes from the Chesapeake Bay. J. Exp. Mar. Biol. Ecol., 54, 21-38.

Essink, K. \& Kleef, H. L. 1993. Distribution and life cycle of the north American spionid polychaete Marenzelleria viridis (Verrill, 1873) in the Ems estuary. Neth. J. Aq. Ecol., 27, 237-246.

Hällfors, G., Niemi, Å., Ackefors, H., Lassig, J. \& Leppäkoski, E. 1981. Biological oceanography. In The Baltic Sea (Voipio, A., ed.). Elsevier Oceanogr. Ser., Amsterdam, 30, 219-274.

Hummel, H. 1985. Food intake of Macoma balthica (Mollusca) in relation to seasonal changes in its potential food on a tidal flat in the Dutch Wadden Sea. Neth. J. Sea Res., 19, 52-76.

Kotta, J. 2000. Impact of eutrophication and biological invasions on the structure and functions of benthic macrofauna. Diss. Biol. Univ. Tartu., 63.

Kotta, J. \& Kotta, I. 1998. Distribution and invasion ecology of Marenzelleria viridis in the Estonian coastal waters. Proc. Estonian Acad. Sci. Biol. Ecol., 47, 212-220.

Kotta, J. \& Ólafsson, E. 2003. Competition for food between the introduced exotic polychaete Marenzelleria viridis and the resident native amphipod Monoporeia affinis in the Baltic Sea. J. Sea Res., 342, 27-35.

Kotta, J. \& Orav, H. 2001. Role of benthic macroalgae in regulating macrozoobenthic assemblages in the Väinameri (north-eastern Baltic Sea). Ann. Zool. Fenn., 38, 163-171.

Kotta, J., Orav, H. \& Sandberg-Kilpi, E. 2001. Ecological consequence of the introduction of the polychaete Marenzelleria viridis into a shallow water biotope of the northern Baltic Sea. J. Sea Res., 46, 273-280.

Laine, A. O. 2003. Distribution of soft-bottom macrofauna in the deep open Baltic Sea in relation to environmental variability. Estuar. Coast. Shelf Sci., 57, 87-97.

Leppäkoski, E. \& Olenin, S. 2001. The meltdown of biogeographical pecularities of the Baltic Sea: the interaction of natural and man-made processes. Ambio, 30, 202-209.

McClintock, J. B. \& Baker, B. J. 1997. A review of the chemical ecology and predatory impacts of the nonindigenous crab Carcinus maenas (L.) on early benthic phase Dungeness crab Carcinus magister Dana. J. Exp. Mar. Biol. Ecol., 258, 39-54.

Moyle, P. B. \& Light, T. 1996. Fish invasions in California: do abiotic factors determine success? Ecology, 77, 1666-1670.

Neideman, R., Wenngren, J. \& Ólafsson, E., 2003. Competition between the introduced polychaete Marenzelleria sp. and the native amphipod Monoporeia affinis in Baltic soft bottoms. Mar. Ecol. Prog. Ser., 264, 49-55.

Ólafsson, E. B. 1986. Density dependence in suspension-feeding and deposit-feeding populations of the bivalve Macoma balthica: a field experiment. J. Anim. Ecol., 55, 517-526.

Olenin, S. \& Leppäkoski, E. 1999. Non-native animals in the Baltic Sea: alteration of benthic habitats in coastal inlets and lagoons. Hydrobiologia, 393, 233-243.

Ruesink, J. L., Parker, I. M., Groom, M. J. \& Kareiva, P. M. 1995. Reducing the risks of nonindigenous species introductions: guilty until proven innocent. Bioscience, 45, 465-477.

Russel, D. E. 1995. The diurnal vertical migration of Marenzelleria viridis (Polychaeta: Spionidae) in the Chester River. Am. Zool., 35, 115A.

Segerstråle, S. G. 1957. Baltic Sea. Mem. Geol. Soc. Am., 67, 757-800.

Simberloff, D. 1991. Keystone species and community effects of biological introductions. In Assessing Ecological Risks of Biotechnology (Ginzburg, L. R., ed.), pp. 1-19. Butterworth-Heinemann, Boston. 
Sokal, R. R. \& Rohlf, F. J. 1981. Biometry. The Principles and Practice of Statistics in Biological Research. Second edition. W. H. Freeman, San Francisco.

Stigzelius, J., Laine, A., Rissanen, J., Andersin, A.-B. \& Ilus, E. 1997. The introduction of Marenzelleria viridis (Polychaeta, Spionidae) into the Gulf of Finland and the Gulf of Bothnia (northern Baltic Sea). Ann. Zool. Fenn., 34, 205-212.

Zettler, M. L. 1996. Successful establishment of the spionid polychaete, Marenzelleria viridis (Verrill, 1873), in the Darss-Zingst estuary (southern Baltic) and its influence on the indigenous macrozoobenthos. Arch. Fish. Mar. Res., 43, 273-284.

Zettler, M. L., Bochert, R. \& Bick, A. 1994. Röhrenbau und Vertikalverteilung von Marenzelleria viridis (Polychaeta: Spionidae) in einem inneren Küstengewässer der südlichen Ostsee. Rostock Meeresbiol. Beitr., 2, 215-225.

Zettler, M. L., Daunys, D., Kotta, J. \& Bick, A. 2002. History and success of an invasion into the Baltic Sea: the polychaete Marenzelleria cf. viridis, development and strategies. In Invasive Aquatic Species of Europe - Distribution, Impacts and Management (Leppäkoski, E., Gollasch, S. \& Olenin, S., eds.), pp. 66-75. Kluwer Academic Publishers, Dordrecht, The Netherlands.

\title{
Muutused põhjaloomastiku toitumiskäitumises introdutseeritud hulkharjasussi Marenzelleria viridis mõju karbile Macoma balthica
}

\author{
Jonne Kotta, Helen Orav-Kotta ja Eva Sandberg-Kilpi
}

Laborikatsete käigus uuriti suurselgrootute toitumiskäitumist. $M$. balthica toitub palju laiemal alal kui $M$. viridis. M. viridis'e esinemisel suurenevad $M$. balthica toitumisala ja toiduotsingu aktiivsus oluliselt. Tulemused viitavad sellele, et $M$. balthica konkurentsieelis hulkharjasussi $M$. viridis ees on tingitud karbi efektiivsemast toitumisstrateegiast. Konkurentsisuhteid nende kahe liigi vahel võib pidada peamiseks faktoriks, mis piirab hulkharjasussi $M$. viridis edasist levikut Läänemeres. 